\title{
A method of outdoor housing dairy calves in pairs using individual calf hutches
}

\author{
L. Wormsbecher, ${ }^{*}$ R. Bergeron, ${ }^{*}$ D. Haley,† A. M. de Passillé,ł J. Rushen, $\ddagger$ and E. Vasseur ${ }^{1}$ \\ *Department of Animal Biosciences, University of Guelph, Guelph, Ontario, N1G 2W1, Canada \\ †Ontario Veterinary College, University of Guelph, Guelph, Ontario, N1G 2W1, Canada \\ ‡Dairy Education and Research Centre, University of British Colombia, Agassiz, British Colombia, V0M 1A0, Canada \\ §Department of Animal Science, McGill University, Ste-Anne-de-Bellevue, Quebec, H9X 3V9, Canada
}

\begin{abstract}
Interest in housing dairy calves in groups is currently growing. Group housing using individual calf hutches, a resource already available in most dairy farms in North America, could provide a novel housing method that can be a simple way to implement group housing on farm. The main objective of this study was to determine whether pair housing dairy calves in hutches outdoors would result in similar weight gain and milk intake compared with individual housing in hutches. The study was designed to avoid competition for resources (including milk and solid feed, teat, bucket, outdoor space, and hutch) to test a setup that has the potential to maximize performance and calf growth. Secondary objectives were to document how calves in both treatments use their environment in terms of time spent and behaviors performed in each area, how paired calves interact, and the time they spend together. Single calves $(\mathrm{n}=6$ /season) were housed in 1 hutch with an attached outdoor environment; paired calves ( $\mathrm{n}=6$ pairs/season) were given twice the resources. Calves were fed up to $16 \mathrm{~L} / \mathrm{d}$ of milk replacer. Daily milk intake and weekly weight gains were recorded. Behavioral observations were recorded live once per week for 5 (summer) or 4 (winter) nonconsecutive periods. Paired and single calves had similar weight gain (averaging from 1.1 to $1.3 \mathrm{~kg} / \mathrm{d}$ across trials) and milk intake (averaging from 11.1 to $13.7 \mathrm{~kg} / \mathrm{d}$ across trials), showing no difference in performance between treatments. Low occurrences of cross sucking (averaging from 0.1 to 0.4 bouts/h of observation per pen across trials) and displacements at the teat ( 0.8 to 1.4 bouts/h of observation per pen across trials) were found. All calves altered their behavior in some way to accommodate companions; paired calves were seen interacting and spending time together (i.e., lying in the same hutch), and in the summer trial
\end{abstract}

Received January 5, 2017.

Accepted May 23, 2017.

${ }^{1}$ Corresponding author: elsa.vasseur@mcgill.ca single calves spent less time lying inside the hutch than paired calves, presumably to have visual access to other calves. The solution of mixed indoor and outdoor housing environments tested as part of this study showed that calves make use of all spaces provided to them in winter and in summer conditions while maintaining good performance. Housing calves in pairs using individual hutches can be a suitable alternative to housing calves individually in hutches outdoors.

Key words: dairy calf, calf hutch, social housing, outdoor housing

\section{INTRODUCTION}

Dairy farmers in the United States and Canada still routinely house their replacement heifers individually either in hutches or in single pens (USDA, 2010; Vasseur et al., 2010), and calves typically have visual contact with one another (Marcé et al., 2010). Grouphoused calves have been shown to have higher intakes of solid feed and improved BW gains compared with individually housed calves (Babu et al., 2004; De Paula Vieira et al., 2010) and are able to interact socially and perform natural behaviors such as social licking and play behavior (Sato et al., 1993; Faerevik et al., 2007; Jensen et al., 2008). This study examined whether it would be possible for producers to use existing individual hutches - a resource already available on most dairy farms - as an alternative to remodeling their calf barn to provide group housing for calves.

The social isolation that occurs with individual housing is thought to be stressful for calves and can prevent the learning of social behaviors (Duve and Jensen, 2011). Some studies have shown that individually housed calves have an impaired ability to socialize with other calves (De Paula Vieira et al., 2010; Jensen and Larsen, 2014). The increased social interaction found in paired housing can be beneficial to the calf with respect to learning social cues as well as adapting to future changes in the feeding system or environment (Costa et al., 2014). 
One reason why producers have shied away from group housing in the past is that cross sucking and competition at the feeder can occur. Cross sucking is a nonnutritive sucking behavior (Rushen and de Passillé, 1995) that can lead to hair loss and inflammation of the sucked area (Sambraus, 1980). However, cross sucking can be decreased when calves are allowed to suck for their milk or are able to redirect their sucking motivation to a dry teat on the wall (Veissier et al., 2002). Displacements at the teat can also be a problem with group housing, but this can be managed by providing more teats (von Keyserlingk et al., 2004). Some authors have looked at whether pair housing can yield improvements in calf welfare that are similar to the improvements group housing yields and found similar weight gains and milk intakes as in group housing (Cobb et al., 2014) and individual housing (Chua et al., 2002). As well, calves housed in pairs can benefit from the social contact provided by a companion (Meagher et al., 2015). Producers have already invested in hutches, so pair housing in individual hutches may be a way to provide social enrichment. Calves housed in hutches typically are tethered or enclosed in a small pen (Davis et al., 1954; Macaulay et al., 1995); raising them loose in a larger outdoor pen could provide them with spatial or physical enrichments. An enrichment can be considered as anything that helps prevent frustration in the animal or helps fulfill the animal's needs (Mandel et al., 2016). This outdoor area would allow calves to run more when paired together, provide multiple areas inside or outside the hutch for the animals, and provide the choice to have physical contact (Ninomiya and Sato, 2009). Much research has looked at the effect of hutch housing in summer (Moore et al., 2012; Carter et al., 2014; Friend et al., 2014); however, little research has examined outdoor hutch housing in winter. A previous experiment by Pempek et al. (2016) looked at Jersey calves allocated to individual or pair housing 1 hutch in both treatments regarding the number of calves, and restricted milk feeding; the experiment was conducted from late summer to mild Ohio winter. No difference in ADG between treatments or effect of temperature on calf performance was found, but numerous cross sucking and nonnutritive behaviors were observed in both treatments. As a very first step in building recommendations for outdoor housing in cold winter as experienced in Eastern Canada, some research has been conducted to test dairy cattle preference for the outdoors when the option is offered to animals in these climatic conditions. Krohn et al. (1992) reported that cows reduced their time spent outside during extreme adverse weather conditions and preferred to stay indoors when the temperature dropped below $0^{\circ} \mathrm{C}$. However, Shepley et al. (2017) showed that dairy cows accustomed to year-long outdoor access choose to spend a minimum of $1 \mathrm{~h} / \mathrm{d}$ outdoors during Eastern Canadian winter conditions, even with cold temperatures and snow coverage, indicating that previous experience may play a role in cattle preference for being outdoors. Based on those investigations on adult cattle, the feasibility of a mix of indoor and outdoor environments in dairy calves should be tested in both winter and summer.

In this experiment we compared single and paired calves housed in hutches with an outdoor enclosure and unlimited feed access. The study was designed to avoid competition for resources (including milk and solid feed, teat, bucket, outdoor space, and hutch) to test a setup that has the potential to maximize performance and calf growth. The objective of this experiment was to test how single and paired calves would perform when provided with the best setup possible and to replicate the study in both summer and winter to evaluate how calves would perform in this system in both seasons. Our first objective was to determine whether growth and feed intake differ between single and paired calves. Our second objective was to determine how single and paired calves use their environment in terms of time spent and behaviors performed in each area. Our third objective was to document the interaction between paired calves and the time they spend together. Both a summer trial and a winter trial were conducted to see whether the housing method was successful under Canadian extremes.

\section{MATERIALS AND METHODS}

The experiment was conducted at the University of Guelph's Alfred Campus (Alfred, Ontario, Canada) and was approved by the University of Guelph's Animal Care Committee, which adheres to the Canadian Council on Animal Care (2009) guidelines. A summer trial was conducted during the months of June to August of 2014 , whereas a winter trial was conducted during the months of February to April of 2015.

\section{Animals, Housing, and Management}

For each trial, 18 Holstein heifer calves were purchased from external sources before the start of the trial. Upon arrival at the experimental site, the calves were randomly assigned to 2 treatments - housed either as singles ( $\mathrm{n}=6$ calves for each season) or as pairs ( $\mathrm{n}$ $=6$ pairs, or 12 calves, for each season) - blocked by time of arrival on farm. Single calves had access to a $6.9-\mathrm{m}^{2}$ outdoor pen and 1 plastic hutch $\left(2.4 \mathrm{~m}^{2}\right.$ of indoor space). Indoor and outdoor areas were exactly doubled for paired calves $\left(13.7 \mathrm{~m}^{2}\right.$ of outdoor space and $4.8 \mathrm{~m}^{2}$ of indoor space in 2 hutches). No shade was pro- 
vided besides the sun protection offered by the hutches. Each pen was constructed using wire cattle fencing on a compacted sand base $15 \mathrm{~cm}$ deep. Straw bedding was added at a minimum of $20 \mathrm{~cm}$ for each hutch. Manure was removed $4 \mathrm{~d} /$ wk and straw was added $3 \mathrm{~d} /$ wk or as needed to ensure a dry indoor and outdoor environment. Additional straw was provided outdoors after precipitation when calf pens were wet.

Calves were brought to the farm at an average $( \pm \mathrm{SE})$ of $7.5 \mathrm{~d}$ ( \pm 1.6 ; age of calves on arrival to the farm was estimated based on auction receipts because no records of birth were transferred) and after a period of adaptation (minimum of $12 \mathrm{~d}$ ); they were approximately 24.0 $\mathrm{d}( \pm 4.3)$ when the trial began. The adaptation period was used to adjust calves to the high milk allowance and the milk feeding method. Calf general condition (i.e., health and vigor) was evaluated visually upon arrival, and navels were dipped in iodine (7\% iodine solution) to prevent bacterial infection. Calves were given $1 \mathrm{~mL}$ of tulathromycin (Draxxin; Pfizer Animal Health, Kirkland, Québec, Canada) and $1 \mathrm{~mL}$ of selenium (Dystosel; Pfizer Animal Health) as prevention and to decrease the incidence of illness following MillerCushon et al. (2013). Calves were also given $2 \mathrm{~mL}$ of a bovine rhinotracheitis-parainfluenza-respiratory-syncytial virus vaccine (modified live virus; Inforce 3; Zoetis Canada, Kirkland, Québec, Canada) as prevention against respiratory disease and influenza. During the summer trial 2 calves were treated by the veterinarian; 1 calf (paired treatment) was treated for coccidiosis and ulcers and was removed from the trial for $7 \mathrm{~d}$, and 1 calf (individual treatment) was treated for a navel infection but was kept enrolled in the trial. During winter, no calves required medical treatment once the trial began.

\section{Milk and Grain Feeding}

During the summer trial, acidified milk replacer was delivered $2 \times / \mathrm{d}$ in high quantities (beginning at $12 \mathrm{~L} / \mathrm{d}$ and working up to $16 \mathrm{~L} / \mathrm{d}$ per calf, adjusting based on how much the calf drank voluntarily) using an artificial teat attached to the fence, with a rubber tube running from the artificial teat (Peach Teats; Skellerup Industries Ltd., Woolston, New Zealand) to a bucket placed on the ground outside the pen. Shur-Gain Optivia High Performance milk replacer (22\% CP and 18\% fat; Nutreco Canada Inc., Guelph, Ontario, Canada) was mixed at $150 \mathrm{~g}$ of powder to $1 \mathrm{~L}$ of water and was acidified using 9.8\% dilute formic acid (The Acidified Milk Solution; NOD Apiary Products Ltd., Frankford, Ontario, Canada) following Ontario Ministry of Agriculture, Food and Rural Affairs protocol (Anderson, 2012). A one-way valve was attached to the end of the tube inside the bucket to prevent backflow of milk.
Buckets were thoroughly cleaned and sanitized $2 \times / d$; teats and tubes were cleaned and sanitized thoroughly $1 \times / d$ and rinsed a second time.

The feeding method was adapted for the winter trial to prevent milk from freezing and to provide a milk allowance that was consistent with that of the summer trial. Milk replacer was available for $30 \mathrm{~min}$ to $1 \mathrm{~h} /$ feeding or as long as the calf had continued interest in the teat. Nonacidified milk replacer was fed $3 \times / d$ by attaching an artificial teat to the side of a bucket. The bucket was then attached to the pen wall at an appropriate height that allowed calves to drink. Buckets and teats were thoroughly cleaned and sanitized $3 \times / \mathrm{d}$ immediately following the feeding period.

Calves had access to $200 \mathrm{~g}$ of calf starter (Rooney $20 \%$ Calf Starter Grower Medicated, Iroquois, Ontario, Canada) from $\mathrm{d} 1$ of the trial. Starter was gradually increased to $2 \mathrm{~kg} / \mathrm{d}$ at the start of weaning and increased up to $2.5 \mathrm{~kg} / \mathrm{d}$ by the end of weaning. Hay and water were provided ad libitum. Hay, water, and grain were provided using a bucket for each calf to limit competition in the paired pens ( 3 buckets/calf). Calves were weaned gradually at $49 \mathrm{~d}$ ( $41 \mathrm{~d}$ for winter) of the trial by gradually decreasing milk allowance by $10 \%$ of initial milk intake for $10 \mathrm{~d}$ following de Passillé et al. (2010). All data presented refer to the preweaning period.

\section{Measures}

Feed Intake. Milk intake was measured daily based on difference in weight of offered and refused milk replacer. Grain refusals were recorded daily 3 wk before the start of weaning once intake increased beyond 50 $\mathrm{g} / \mathrm{d}$.

Growth. Calves were weighed $1 \times /$ wk on a scale (Brecknell PS-2000 Scale; Brecknell Canada, PointeClaire, Québec, Canada) that was calibrated weekly before each weighing to ensure accurate readings.

Lying Time. Throughout the duration of each trial, the posture of each calf (lying or standing) was recorded continuously for $24 \mathrm{~h}$ over $7 \mathrm{~d}$ with 1 recording/ min to monitor resting behavior and ensure that the housing method allowed calves to rest enough. Activity loggers (Hobo Pendant G Acceleration Data Logger, Onset Computer Corp., Bourne, MA) were placed on the lateral aspect of the leg along the metatarsus bone on alternating (each 7-d period) hind legs every $1 \mathrm{wk}$ (winter) or every 2 wk (summer) following the procedure of Bonk et al. (2013).

Space Usage, Social Interactions, and Redirected Behavior. Live behavioral observations were done $1 \times /$ wk for 7 nonconsecutive $\mathrm{hr}$ ( 5 periods; between 0730 and $2030 \mathrm{~h}$ ) in summer and 6 nonconsecutive $\mathrm{hr}$ 
Table 1. Ethogram of observed behaviors

\begin{tabular}{lll}
\hline Behavior & Description & Adapted from \\
\hline Cross sucking & $\begin{array}{l}\text { One calf has its head and nose under the belly of a second } \\
\text { calf, or one calf sucking on ear or sucking on vulva. Bout } \\
\text { recorded as finished when calf stops and turns head away. }\end{array}$ & $\begin{array}{l}\text { Chua et al. (2002); de Passillé et al. } \\
(2010)\end{array}$ \\
Allogrooming (social grooming) & $\begin{array}{l}\text { Calves groom or lick each other; one calf may groom or lick } \\
\text { another calf. Bout recorded as finished when calf stops and } \\
\text { turns head away. }\end{array}$ & Boe and Faerevik (2003) \\
Displacement & $\begin{array}{l}\text { One calf displaces another at the nipple; calf then puts } \\
\text { mouth completely on the nipple. }\end{array}$ & von Keyserlingk et al. (2004) \\
Calf is standing in front of nipple and has its head directly & $\begin{array}{l}\text { Hammel et al. (1988); Appleby (2001); } \\
\text { Chua et al. (2002); Miller-Cushon et } \\
\text { in front of or its mouth on the nipple. }\end{array}$ & al. (2013) \\
Drinking milk & $\begin{array}{l}\text { Calf has its head inside the bucket or is standing with head } \\
\text { facing bucket. } \\
\text { Calf has its head in bucket and is standing with head facing }\end{array}$ & Miller-Cushon et al. (2013) \\
the bucket. & $\begin{array}{l}\text { Posture (lying or standing) and location (inside hutch or } \\
\text { outside hutch) of calf were recorded. }\end{array}$ & Faerevik et al. (2008) \\
Spating calf starter & &
\end{tabular}

(4 periods; between 0730 and $1800 \mathrm{~h}$ ) in winter by 2 trained observers (3 different observers in total) over the $7 \mathrm{wk}$ (summer) or $6 \mathrm{wk}$ (winter) of the trial. Study periods were as follows: period 1, 0730 to $0930 \mathrm{~h}$; period 2, 1100 to $1200 \mathrm{~h}$; period 3, 1330 to $1430 \mathrm{~h}$; period 4, 1600 to $1800 \mathrm{~h}$; period 5, 1930 to $2030 \mathrm{~h}$ ). Observers recorded the behavior of different calves at the same time. Each observer was positioned between 2 and $4 \mathrm{~m}$ away from calf pens to view 6 groups of calves ( 3 pairs and 3 singles each) with minimal movement. From their position, observers could see inside the hutch to determine calf posture inside the hutch. Observers took their position 5 min before the observation period began to allow habituation and did not consciously attract the attention of the calves during the observation period. Observers switched position each recording day to prevent bias.

Descriptions of all behaviors observed can be found in Table 1. Interobserver reliability was verified twice during each trial ( $>97 \%$ for all behaviors). Observers sat in the same spot and recorded behavior from the same 6 pens at the same time for at least $3 \mathrm{~h}$ at the beginning and end of each trial. Data from observations were compiled for each observer, observations were compared between the 2 observers, and a percentage was given for related observations. Space usage inside or outside the hutch as well as the posture (lying and standing) of the calf in the pen for paired and singlehoused calves and proximity of the paired calves to each other were recorded every $30 \mathrm{~s}$ for $20 \mathrm{~min}$ each hour of observation. This was then calculated as a percentage of observed time for each week of observations. Space usage was measured to see how often calves used their hutches and whether this amount changed as they grew. Proximity of paired calves to each other was assessed visually by approximating the distance (one calf's length; distance was adjusted as the calves grew) between the calves. This was recorded qualitatively as whether calves were together as part of the space usage observations. During feeding, synchronicity was recorded as when calves were feeding at the same time. Social interactions for paired calves, such as the number of allogrooming, cross sucking, and displacement events that occurred, were recorded for both calves over 2 min of continuous sampling for a total of 20 periods (40 $\mathrm{min} / \mathrm{h})$.

Weather Conditions. Temperature (maximum, average, and minimum) and precipitation (in $\mathrm{mm}$; either rain or snow) were taken from the St-Albert (Ontario) weather station (approximately $33 \mathrm{~km}$ from the Alfred research dairy farm), collected from the Weather Canada website, and reported for each observation week in Table 2.

\section{Sample Size}

When designing our experiment, our aim was to provide a management and housing environment for both pairs and individual calves that limited as much as possible competition for resources and therefore allowed calves to maximize performance and growth while having opportunities to rest and exhibit other natural behaviors. Therefore, the methodology used to determine the number of animals needed for the experiment was based on a literature review of dairy calf studies comparing different management and housing environments varying in level of competition for resources (e.g., milk available, number of teats at the feeder, comfortable resting surface).

Performance was a primary measure of interest in our experiment. Using data from the review by Khan et al. (2011) on ad libitum versus restricted milk feeding 
for unweaned calves, daily weight gain varied between $1.0 \mathrm{~kg} / \mathrm{d}$ (ad libitum) and $0.45 \mathrm{~kg} / \mathrm{d}$ (restricted). The variance was calculated as 0.075 . Based on a confidence level of 0.95 and a power of 0.8 , using a 2-tailed test, the sample size for detecting a significant difference between 2 treatments should be $\mathrm{n}=4 /$ treatment (calculator from EpiTools; http://epitools.ausvet.com. $\mathrm{au})$. Therefore, the choice of $\mathrm{n}=6 /$ treatment in our experiment is adequate for this variable. Regarding milk intake data, using data from Miller-Cushon et al. (2014) comparing competitive and noncompetitive milk feeding environments, milk intake varied between 13.3 L/d (competitive) and $11.7 \mathrm{~L} / \mathrm{d}$ (noncompetitive). The variance was calculated as 0.64 . Using the same conditions as described for daily weight gain, the sample size for detecting a significant difference between 2 treatments should be $\mathrm{n}=4 /$ treatment. Therefore, the choice of $n=6$ /treatment in our experiment is adequate for this variable.

The second type of measure collected as part of our experiment is behavioral data. Data from Miller-Cushon et al. (2014) comparing competitive and noncompetitive milk feeding environments were used to calculate our sample size for displacement frequency during milk feeding, which varied between 11.3/d (competitive) and $2.8 / \mathrm{d}$ (noncompetitive). The variance was calculated as 18.06. Using the same conditions as described for daily weight gain, the sample size for detecting a significant difference between 2 treatments should be $\mathrm{n}=4$ / treatment. Therefore, the choice of $n=6$ /treatment in our experiment is adequate for this variable. As for lying time, data from Camiloti et al. (2012) comparing calves housed on wet versus dry bedding showed variation between 12.2 and $16.8 \mathrm{~h} / \mathrm{d}$ for wet and dry, respectively. The variance was calculated as 5.29. Using the same conditions as described for daily weight gain, the sample size for detecting a significant difference between 2 treatments should be $n=4 /$ treatment. Therefore, the choice of $n=6 /$ treatment in our experiment is adequate for this variable. Overall, $n=6 /$ treatment seemed to be a sufficient number for detecting significant differences between our 2 treatments for both performance and behavioral data if the management and housing environment provided to pairs was not successful in eliminating competition for resources.

\section{Statistical Analyses}

Summer and winter trials were analyzed separately because of large differences in climatic conditions and therefore could not be considered as replicates. Space usage data from each observation period were collated in percentage of observed time. Space usage, milk intake, and weight gain data were analyzed at the pen level and were obtained for the paired calves by taking the mean value of the 2 calves. All data were tested for normality using the UNIVARIATE procedure in SAS (SAS Institute Inc., 2011) or by plotting the residuals. Data found to be normal (weight gain and milk intake) were analyzed using the MIXED procedure, whereas data found to be not normal were transformed using an arcsine transformation (space usage and activities performed) or a square root transformation (lying time). All data presented in this article are untransformed.

Table 2. Maximum, average, and minimum temperature and precipitation for each week for the summer and winter trials ${ }^{1}$

\begin{tabular}{|c|c|c|c|c|c|}
\hline Trial & Week & $\begin{array}{l}\text { Maximum } \\
\text { temperature, }{ }^{\circ} \mathrm{C}\end{array}$ & $\begin{array}{c}\text { Average } \\
\text { temperature, }{ }^{\circ} \mathrm{C}\end{array}$ & $\begin{array}{c}\text { Minimum } \\
\text { temperature, }{ }^{\circ} \mathrm{C}\end{array}$ & $\begin{array}{c}\text { Precipitation, } \\
\text { mm }\end{array}$ \\
\hline \multicolumn{6}{|c|}{ Summer } \\
\hline & 1 & 22.5 & 17.0 & 11.5 & $9.0^{2}$ \\
\hline & 2 & 23.5 & 17.3 & 11.0 & 0.0 \\
\hline & 3 & 27.0 & 22.3 & 17.5 & 0.0 \\
\hline & 4 & 22.0 & 19.8 & 17.5 & 0.0 \\
\hline & 5 & 23.0 & 17.3 & 11.5 & 0.0 \\
\hline & 6 & 23.5 & 17.8 & 12.0 & 0.0 \\
\hline & 7 & 26.0 & 20.0 & 14.0 & 0.0 \\
\hline \multicolumn{6}{|c|}{ Winter } \\
\hline & 1 & -8.8 & -12.9 & -16.8 & $0.6^{3}$ \\
\hline & 2 & -7.5 & -13.7 & -19.8 & $2.0^{3}$ \\
\hline & 3 & 0.0 & -6.4 & -12.8 & $1.3^{3}$ \\
\hline & 4 & 0.5 & -5.5 & -11.5 & $1.3^{3}$ \\
\hline & 5 & 1.5 & -1.7 & -4.8 & 0.0 \\
\hline & 6 & -1.3 & -5.9 & -10.9 & 0.0 \\
\hline
\end{tabular}

${ }^{1}$ Information taken from the St. Albert weather station (located $34 \mathrm{~km}$ from the research station) and collected from the Weather Canada website (http://climate.weather.gc.ca/climate_data/).

${ }^{2}$ Indicates rain as precipitate.

${ }^{3}$ Indicates snow as precipitate. 
The effect of treatment (single vs. pair), week, and their interaction on weight gain, milk intake, lying time, space usage, and activities performed was tested using the MIXED procedure. Interactions are presented when significant; otherwise, main effects are presented. Starting BW was included as a covariate for weight gain and milk intake. The variance components structure was used as the variance-covariance matrix structure for weight gain, space usage, activities, and lying time, whereas the autoregressive structure was used for the milk intake data. All covariance structures were selected based on the best fit according to Schwarz' Bayesian information criteria. For the pair and single comparison, the group option was also used to state a heterogeneous variance of error. Treatment and treatment $\times$ week interaction were included in the model as fixed effects, pen was included as a random effect, and week was included as a repeated measure. Statistical significance was declared at $P<0.05$. Descriptive statistics were calculated on the percentage of time spent in close proximity; however, no statistical analysis was conducted on these data.

Social interactions and redirected behavior for paired calves (i.e., displacements at the teat, cross sucking, and allogrooming) were collated for each pair of calves $(\mathrm{n}=6)$, each period of observation $(\mathrm{n}=4$ in winter, $\mathrm{n}=5$ in summer), and each week ( $\mathrm{n}=6$ in winter, $\mathrm{n}$ $=7$ in summer) as average number of bouts per $2 \mathrm{~min}$ of observation and then reported as average number of bouts per hour of observation. Average difference in displacement at the teat, cross sucking, and allogrooming between weeks and between periods was tested using Cochran-Mantel-Haenszel statistics (FREQ procedure) adjusting for pairs of calves. As a post hoc test, differences between individual periods were compared using a Wilcoxon signed-rank test (UNIVARIATE procedure), with familywise error rate adjusting for multiple comparisons (new pairwise $\alpha_{\mathrm{B}}=0.04$ ).

\section{RESULTS}

\section{Summer}

Growth and Milk Intake. The ADG and milk intake for each treatment across weeks are reported in Figure 1.There were no differences in growth rate between treatments. Paired and single calves gradually gained weight over time $\left(P_{\text {week }}<0.01\right)$; ADG $( \pm \mathrm{SE})$ was $1.1 \pm 0.06 \mathrm{~kg} / \mathrm{d}$ for paired calves and $1.2 \pm 0.05$ $\mathrm{kg} / \mathrm{d}$ for single calves, with the exception of a decrease in ADG for paired calves in wk 4 (ADG wk 4 for pairs $\left.=0.9 \pm 0.09 \mathrm{~kg} / \mathrm{d} ; P_{\text {treatment } \times \text { week }}<0.1\right)$. Final weights for paired and single calves averaged $106.4 \pm 4.53 \mathrm{~kg}$.
Average daily milk intake was $11.1 \pm 0.29 \mathrm{~kg} / \mathrm{d}$ per calf for paired calves and $12.3 \pm 0.38 \mathrm{~kg} / \mathrm{d}$ per calf for single calves, and all calves increased their milk intake throughout the trial $\left(P_{\text {week }}<0.05\right)$. In week 1 , paired calves drank $2.0 \mathrm{~kg} / \mathrm{d}$ more than single calves $\left(P_{\text {treatment } \times \text { week }}<0.01\right)$.

Lying Time. Except for wk 1, no difference in lying time was found between treatments, with paired calves lying on average $16.5 \pm 0.13 \mathrm{~h} / \mathrm{d}$ and single calves lying $17.4 \pm 0.18 \mathrm{~h} / \mathrm{d}$. A bout frequency of $23.5 \pm 0.51$ bouts/d was found for paired calves, whereas single calves had $28.3 \pm 0.67$ bouts/d. There was no difference in bout frequency between treatments except in wk 3. The mean bout duration was $43.8 \pm 1.40 \mathrm{~min}$ for paired calves and $38.3 \pm 0.81 \mathrm{~min}$ for single calves across the whole trial. Lying time was different between treatments in wk 1 , when single calves lay $0.81 \mathrm{~h}$ longer $\left(P_{\text {treatment }} \times\right.$ week $\left.<0.05\right)$ and had $1.2 \times$ more lying bouts $\left(P_{\text {treatment } \times \text { week }}<0.05\right)$ than pairs. In wk 3 , single calves had $1.2 \times$ more lying bouts than paired calves $\left(P_{\text {treatment }} \times\right.$ week $\left.<0.01\right)$ but did not differ in daily duration of lying or mean bout duration.

Space Usage. Percentages of observed time spent inside and outside the hutch across weeks of the trial are presented in Figure 2. When calves were observed outside the hutch, they spent $38.5 \%$ of the time standing, 33.3 to $47.4 \%$ of the time lying down, and $15.3 \%$ standing and feeding across weeks for both treatments. Of the time paired calves were inside the hutch, they spent more than $80.0 \%$ of the time in the same hutch. Table 3 reports the percentage of time spent inside and outside the hutch and doing activities in each location for each treatment. Paired calves lay $1.8 \times, 1.4 \times, 2.6 \times$, and $4.7 \times$ more inside the hutch than single calves in wk $2,3,6$, and 7 , respectively $\left(P_{\text {treatment } \times \text { week }}<0.05\right.$; Figure $2)$. Single calves stood outside $1.3 \times$ more than paired calves in wk $1\left(P_{\text {treatment } \times \text { week }}<0.05\right)$ but stood outside $1.4 \times$ less and lay outside $1.7 \times$ more than paired calves in wk $7\left(P_{\text {treatment } \times \text { week }}<0.05\right)$.

Feeding Behavior. All calves spent approximately $9.5 \%$ of their observed time across weeks of the trial feeding. More specifically, they spent $4.0 \%$ drinking milk, $3.4 \%$ eating hay, $1.6 \%$ eating grain, and $0.5 \%$ drinking water. Paired calves drank milk and ate hay synchronously for 63.8 and $29.0 \%$ of the observed feeding times, respectively. Negligible amounts of time spent eating grain or drinking water synchronously were found. Single calves spent $1.4 \times$ and $1.7 \times$ more time drinking milk than paired calves in wk 3 and 5 , respectively $\left(P_{\text {treatment } \times \text { week }}<0.05\right)$. Paired calves spent $2.1 \times$ more time eating grain than single calves in wk 4

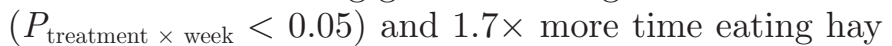
than single calves in wk $7\left(P_{\text {treatment } \times \text { week }}<0.05\right)$. Time 
spent drinking water did not differ between treatments or weeks, and there was no interaction between treatment and week.

Social Interactions and Redirected Behavior for Paired Calves. Social interactions did not differ between weeks $\left(P_{\text {week }}>0.1\right)$, averaging $1.8,0.4$, and 1.4 bouts/h of observations per pen across weeks for allogrooming, cross sucking, and displacements at the teat, respectively. However, all 3 were affected by period of the day $\left(P_{\text {period }}<0.01\right.$ for allogrooming, cross sucking, and displacements at the teat, respectively; Figure 3). Allogrooming was observed more often in period 5 than in any other period $\left(P_{\text {pairwise }}<0.04\right)$. Cross sucking was observed mainly in periods $1(0.6$ bouts $/ \mathrm{h})$ and $5(1.3$ bouts $/ \mathrm{h})$ and was almost nonexistent in periods 2,3 , and $4\left(P_{\text {pairwise }}<0.04\right)$. Displacements at the teat were observed mainly in periods $1(2.7$ bouts/h) and $4(3.2$ bouts $/ \mathrm{h}$ ) and were almost nonexistent in periods 2,3 , and $5\left(P_{\text {pairwise }}<0.04\right)$.

\section{Winter}

Growth and Milk Intake. The ADG for paired calves was $1.3 \pm 0.04 \mathrm{~kg} / \mathrm{d}$, and single calves gained 1.2 $\pm 0.06 \mathrm{~kg} / \mathrm{d}$ across the whole trial; no differences were seen between treatments. Single calves gained $0.3 \mathrm{~kg} / \mathrm{d}$ more in wk 4 than paired calves $\left(P_{\text {treatment } \times \text { week }}<0.05\right.$; Figure 1). There were no effects of treatment or week on daily milk intake, which averaged $13.7 \pm 0.42 \mathrm{~kg} / \mathrm{d}$ across the trial for both treatments. The final average weight for paired and single calves was $115.6 \pm 3.18 \mathrm{~kg}$.

Lying Time. Differences between weeks for daily duration of lying, bout frequency, and mean bout duration can be found in Table 4 . The average daily duration of lying for paired calves was $16.9 \pm 0.11 \mathrm{~h}$ and for single calves was $17.2 \pm 0.07 \mathrm{~h}$ across the trial, with a bout frequency of $20.3 \pm 1.20$ bouts/d for paired calves and $19.9 \pm 0.83$ bouts/d for single calves. Mean bout duration was $51.8 \pm 2.57$ min for pairs and 56.5

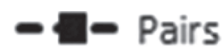

\section{a) Summer}

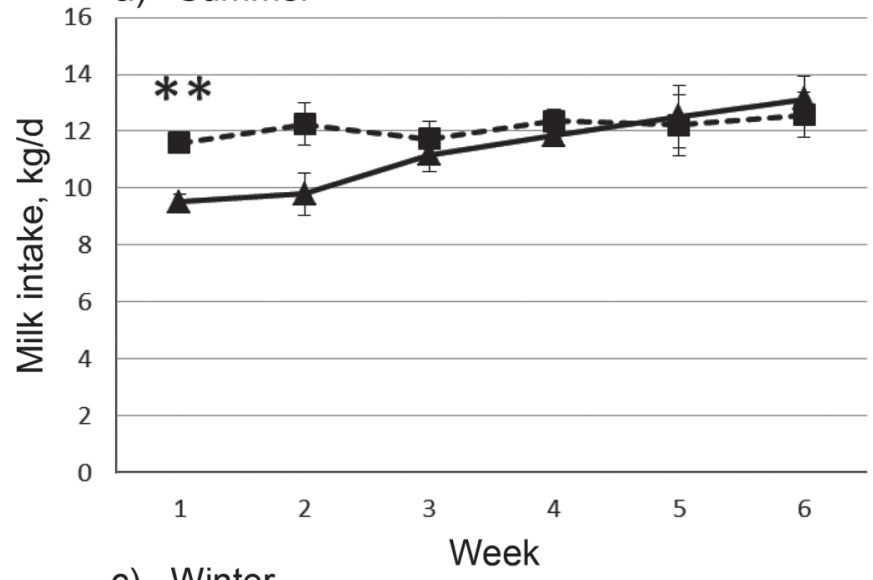

c) Winter

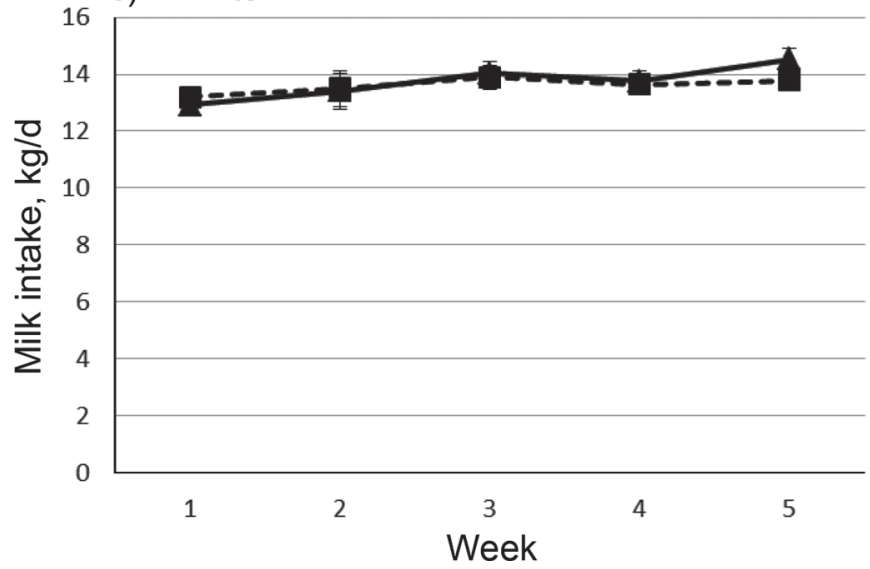

b) Summer

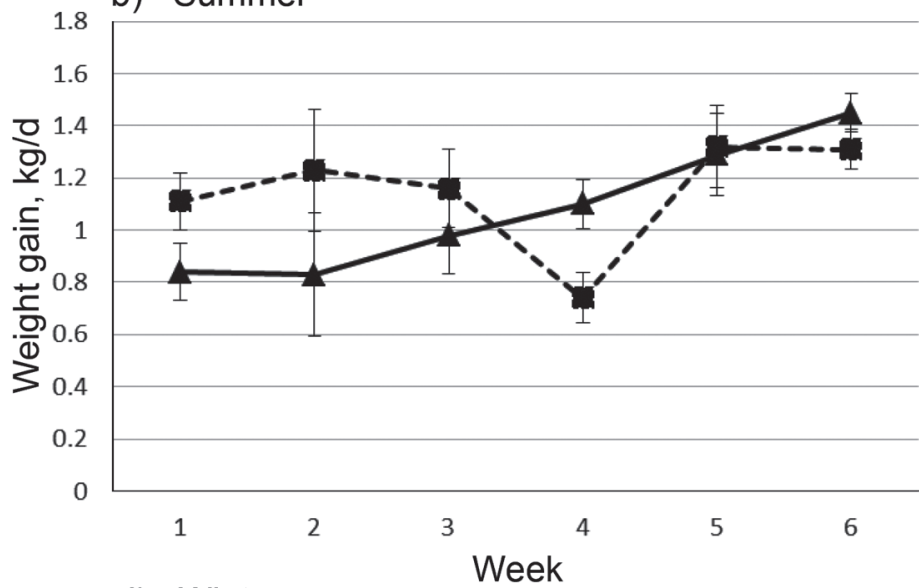

d) Winter

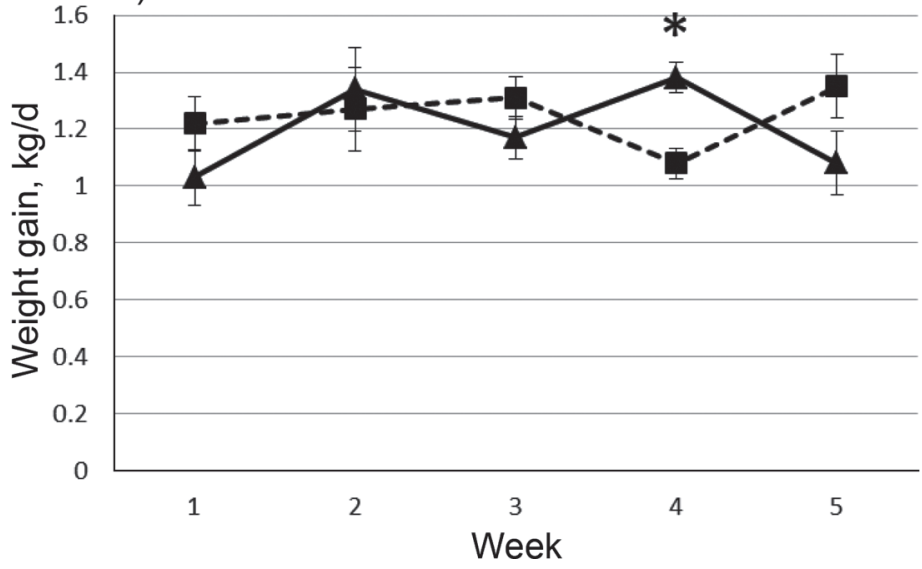

Figure 1. Average daily milk intake (a, c) and ADG (b, d) for summer and winter across the weeks of each trial, with SE bars for both paired and single calves. $* P_{\text {treatment }}<0.05, * * P_{\text {treatment }}<0.01$. 
Table 3. Percentage of observed time paired (P) and single (S) calves spent inside and outside the hutch and performing activities in each location for the summer and winter trials

\begin{tabular}{|c|c|c|c|c|c|c|}
\hline \multirow[b]{2}{*}{ Item } & \multicolumn{2}{|c|}{ Treatment } & \multirow[b]{2}{*}{ SEM } & \multicolumn{3}{|c|}{$P$-value ${ }^{1}$} \\
\hline & $\mathrm{P}$ & S & & Treatment & Week & Treatment $\times$ week \\
\hline \multicolumn{7}{|l|}{ Summer } \\
\hline Inside hutch & 40.6 & 24.3 & 4.63 & 0.0882 & $<0.0001$ & 0.0003 \\
\hline Standing ${ }^{2}$ & 39.6 & 41.6 & 3.08 & NS & $<0.0001$ & NS \\
\hline Lying & 53.3 & 33.7 & 4.77 & 0.0313 & $<0.0001$ & $<0.0001$ \\
\hline Outside hutch & 58.7 & 75.7 & 4.67 & 0.0448 & $<0.0001$ & $<0.0001$ \\
\hline Standing & 40.9 & 36.2 & 2.33 & NS & 0.0001 & 0.0041 \\
\hline Lying & 33.3 & 47.4 & 4.04 & 0.0967 & $<0.0001$ & 0.0044 \\
\hline Standing feeding ${ }^{3}$ & 17.4 & 13.1 & 1.57 & NS & $<0.0001$ & NS \\
\hline \multicolumn{7}{|l|}{ Winter } \\
\hline Inside hutch & 51.7 & 51.2 & 4.42 & NS & 0.0004 & NS \\
\hline Standing ${ }^{2}$ & 57.9 & 62.3 & 5.77 & NS & NS & NS \\
\hline Lying & 33.7 & 24.6 & 2.56 & 0.0587 & NS & NS \\
\hline Outside hutch & 47.5 & 48.7 & 4.49 & NS & 0.0378 & NS \\
\hline Standing & 41.5 & 46.8 & 3.14 & NS & 0.0030 & NS \\
\hline Lying & 19.9 & 15.5 & 2.57 & NS & $<0.0001$ & NS \\
\hline Standing feeding ${ }^{3}$ & 33.1 & 34.6 & 2.68 & NS & 0.0241 & NS \\
\hline
\end{tabular}

${ }^{1} \mathrm{NS}=$ not significant $(P>0.1)$

${ }^{2}$ Standing includes only when the calf is standing idle and not engaged in other activities.

${ }^{3}$ Standing feeding includes all feeding activities while standing or drinking milk or water, which were always performed in a standing position.

a) Inside Hutch

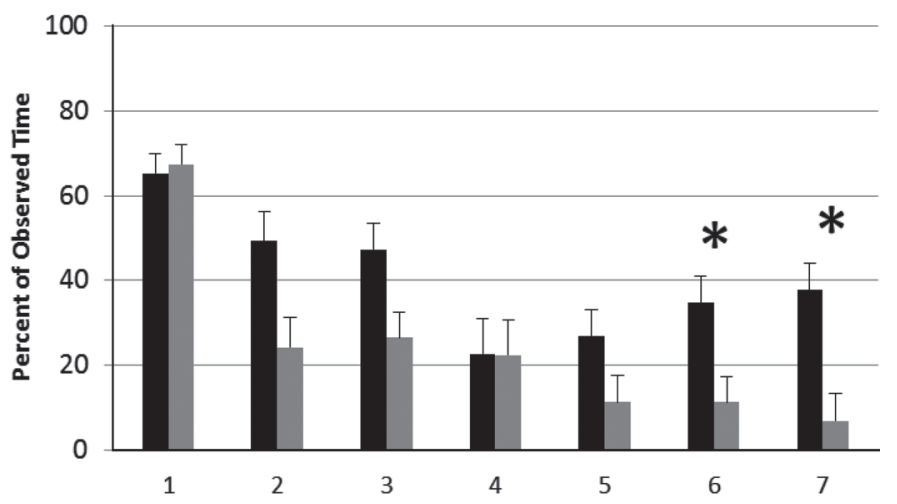

b) Outside Hutch Week

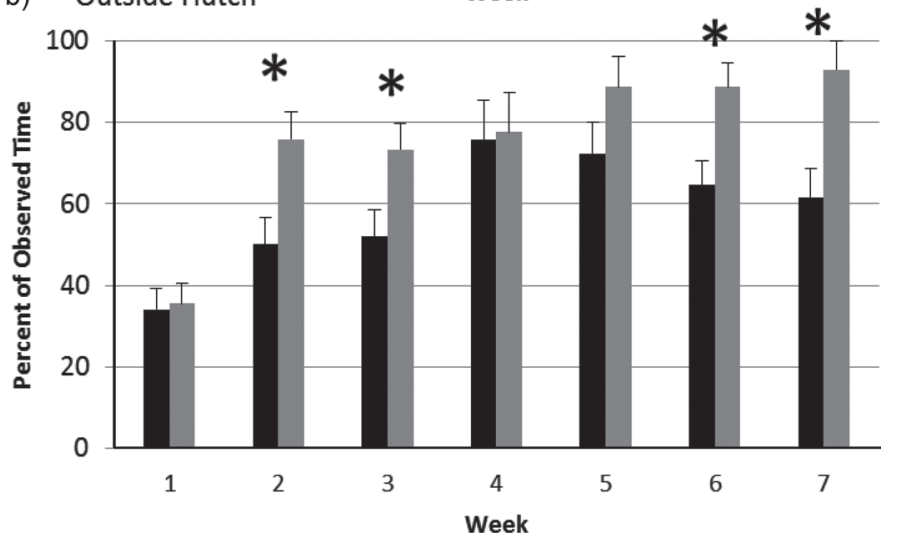

Figure 2. Percentage of observed time that paired (black) and single (gray) calves were seen inside the hutch and outside during the summer trial, with SE bars for both paired and single calves. ${ }^{*} P_{\text {treatment }}$ $<0.05$. \pm 3.72 min for singles across the whole trial. There was no treatment or interaction significance for daily duration of lying, bout frequency, or mean bout duration, but a week effect was observed for all 3 variables. Daily duration of lying peaked in wk 3 and 4 and then decreased to lower levels in wk $6\left(P_{\text {week }}<0.01\right)$. Bout frequency followed a similar pattern, peaking in wk 4 $\left(P_{\text {week }}<0.01\right)$, whereas mean bout duration followed an opposite pattern, peaking in wk 1 and then decreasing in wk 4 before increasing slightly in wk $6\left(P_{\text {week }}<0.01\right)$.

Space Usage. Percentages of observed time spent inside and outside the hutch and activities performed in each area of the pen are presented in Table 3. No differences were found between the 2 treatments for time spent standing or lying either inside or outside the hutch. Calves in both treatments used the hutch approximately $55.0 \%$ of the time. Of the time paired calves spent inside the hutch, they spent more than $80.0 \%$ of observed time in the same hutch across the whole trial. All calves spent $1.3 \times$ and $1.4 \times$ more time inside the hutch in wk $5\left(P_{\mathrm{wk} 1-5}<0.05\right)$ and $6\left(P_{\mathrm{wk} 1-6}\right.$ $<0.01$ ), respectively, than in wk 1 . Percentage of observed time that all calves spent lying outside across all weeks is presented in Figure 4.

Feeding Behavior. No differences were found between treatments over the trial for each feeding behavior. All calves spent approximately $14.1 \%$ of observed time feeding over the whole trial - approximately $5.0 \%$ drinking milk, $6.5 \%$ eating hay, $1.1 \%$ eating grain, and $1.5 \%$ drinking water. Paired calves spent $75.9 \%$ of the time drinking milk synchronously, $38.6 \%$ eating hay 
Table 4. Daily duration of lying, bout frequency, and mean bout duration (least squares means \pm SE) for all calves (paired and single treatments) at each week of the winter trial

Week

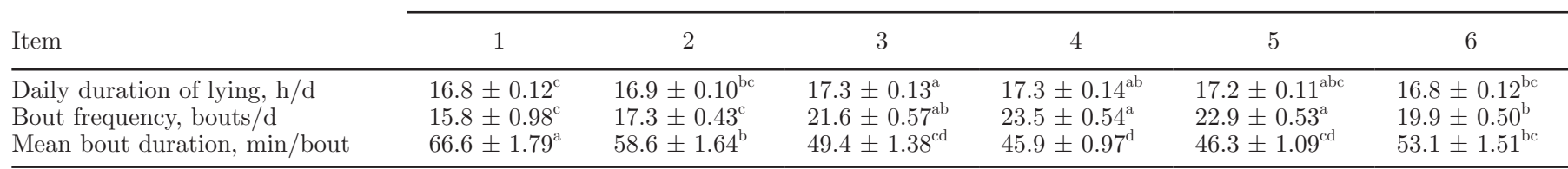

${ }^{\mathrm{a}-\mathrm{d}}$ Different superscripts within a row show differences between individual weeks $(P<0.05)$.

synchronously, and negligible amounts of time eating grain or drinking water synchronously. In wk 1 , paired calves spent $1.4 \times$ more time drinking milk than single calves $\left(P_{\text {treatment } \times \text { week }}<0.01\right)$.

Social Interactions and Redirected Behavior for Paired Calves. Social interactions did not differ between weeks $\left(P_{\text {week }}>0.1\right)$, averaging $2.4,0.1$, and 0.8 bouts/h of observation per pen across weeks for allogrooming, cross sucking, and displacements at the
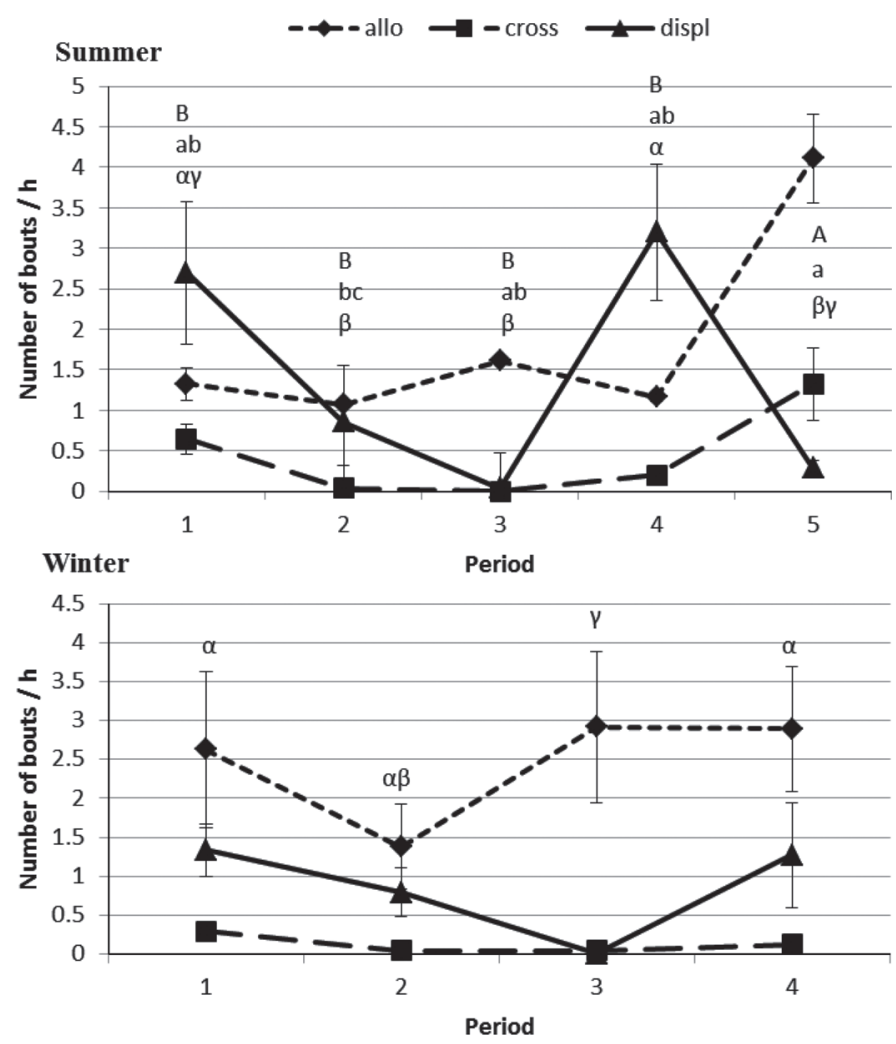

Figure 3. Average ( $\pm \mathrm{SE}$ ) number of bouts of allogrooming (allo) cross sucking (cross), and displacements (displ) for each period of the day for summer and winter trials. Different uppercase Latin letters (A, B) signify differences between periods for allogrooming, different lowercase Latin letters $(\mathrm{a}-\mathrm{c})$ signify differences between periods for cross sucking, and different Greek letters $(\alpha-\gamma)$ signify differences between periods for displacements $\left(P_{\text {pairwise }}<0.04\right)$. The periods are defined as follows: period 1, 0730-0930 h; period 2, 1100-1200 h; period 3, 1330-1430 h; period 4, 1600-1800 h; period 5, 1930-2030 h. teat, respectively. However, both cross sucking and displacements at the teat were affected by period of the day $\left(P_{\text {period }}<0.05\right.$; Figure 3$)$. Displacement at the teat was observed more often in periods 1 and 4 than in period $3\left(P_{\text {pairwise }}<0.04\right)$.

\section{DISCUSSION}

\section{Growth and Milk Intake}

Calves' growth falls within the range of 1.0 to $1.2 \mathrm{~kg} / \mathrm{d}$ previously reported for calves fed ad libitum (Chua et al., 2002; Borderas et al., 2009; Miller-Cushon et al., 2013). Throughout both trials there were no differences in growth rate between treatments except for $1 \mathrm{wk}$ in the summer and winter trials, for which no explanation could be provided (i.e., unknown weather conditions). Even though a lack of difference between treatments could be attributed to the small sample size, our results are supported by other studies looking at paired and single calves fed a high milk allowance and reporting similar growth rates (Chua et al., 2002; De Paula Vieira et al., 2010; Duve and Jensen, 2012).

Milk intake in both seasons fell within the range of 11.4 to $16.1 \mathrm{~L} / \mathrm{d}$ reported in other studies in which

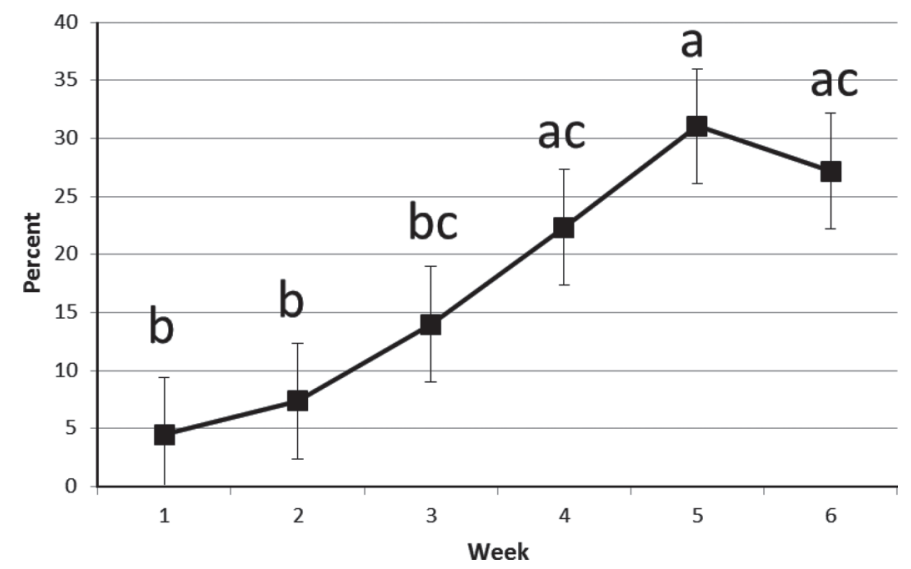

Figure 4. Percentage $( \pm \mathrm{SE})$ of observed time spent lying outside for all calves across weeks for the winter trial. Different letters $(\mathrm{a}-\mathrm{c})$ represent differences between weeks $\left(P_{\text {week }}<0.05\right)$. 
calves were fed ad libitum or a high milk allowance of fresh or acidified milk replacer (von Keyserlingk et al., 2004; Miller-Cushon et al., 2013). On average, calves did not reach the high level of $16.1 \mathrm{~L} / \mathrm{d}$ reported by Miller-Cushon et al. (2013), but some individuals did toward 8 wk of age. The only difference seen in milk intake between treatments was during the first week of the summer trial, where paired calves drank on average $2.0 \mathrm{~kg} / \mathrm{d}$ more liquid milk replacer than single calves. A higher overall milk intake in paired calves compared with single calves $-0.79 \mathrm{~kg} / \mathrm{d}$ of milk replacer DM $(5.3$ $\mathrm{L} / \mathrm{d}$ ) for paired calves compared with $0.74 \mathrm{~kg} / \mathrm{d}$ of milk replacer DM $(4.9 \mathrm{~L} / \mathrm{d})$ for single calves - was also observed by Hepola et al. (2006). Paired calves may have drank more in the first week because of social learning; social facilitation can contribute to how calves adjust to a new environment and to the social learning of new feeding methods (Nicol, 1995).

\section{Feeding Behavior}

Overall, single and paired calves ate for approximately the same amount of time $(9.0 \%$ in summer and $14.3 \%$ in winter). During the summer in wk 3 and 5 , single calves spent more time drinking milk than paired calves. Considering that milk intakes were similar across the whole trial, it is possible that the single calves spent more time sucking the milk teat even when no milk was available or that the taste of the milk on the teat could stimulate a period of sucking if calves finished the milk given in the teat bucket (de Passillé et al., 1992; Rushen and de Passillé, 1995). Alternatively, because the paired calves had the option for social interaction, the single calves may have had to find other ways to occupy their time. Jensen and Larsen (2014) reported that the single-housed calves in their study sniffed and licked the fixtures inside the pen more than paired calves; however, it should be noted that these authors restricted calves to $9 \mathrm{~L} / \mathrm{d}$. Paired calves were able to socialize and lick each other, whereas single calves were unable to perform those activities. Paired calves drank milk simultaneously most of their total time spent drinking milk. Behavioral synchrony occurs when animals perform behaviors together or at the same time (Asher and Collins, 2012). Miller-Cushon et al. (2014) also measured milk feeding synchrony and found that across weeks synchrony ranged from 41.3 to $79.9 \%$ (which includes the percentage found in this trial), suggesting that calves drank milk together or at the same time for a majority of the milk feeding. However, it is documented that most milk feeding occurs around milk delivery time (Appleby, 2001; MillerCushon et al., 2013), which would contribute to the behavioral synchrony.

\section{Lying Time and Space Usage}

Through both summer and winter trials there was no difference between treatments with regard to daily duration of lying (with the exception of wk 1 in the summer trial). All calves spent approximately $17.0 \mathrm{~h} / \mathrm{d}$ lying down, which falls in the range of 16.8 to 18.5 h previously reported (Chua et al., 2002; Jensen and Larsen, 2014). Both Jensen and Larsen (2014) and Chua et al. (2002) found no differences between individually housed and pair-housed calves with regard to the amount of time spent lying.

The winter trial had an average maximum daily temperature of $-1.7^{\circ} \mathrm{C}$ and an average minimum daily temperature of $-10.7^{\circ} \mathrm{C}$. The differences between the weeks of the winter trial in lying time, bout frequency, and duration are difficult to explain. Steers have been reported to lie down more at lower temperatures (Redbo et al., 1996; Tripon et al., 2014), whereas calves have laid the same amount across 4 different ambient temperatures in controlled indoor environments $(5,9,13$, and $18^{\circ} \mathrm{C}$; Schrama et al., 1993). The average minimum temperature during the outdoor winter trial for Tripon et al. (2014) was $3^{\circ} \mathrm{C}$. However, the ambient temperatures experienced by calves in our winter trial were lower than in previous studies, and calves were older than reported by Schrama et al. (1993). Even though wide variations in daily temperature were observed throughout this study, peaks in lying did not correspond to lower temperatures. It should be noted, however, that we did not measure the temperature inside the hutch. Hutches were insulated with snow around the outside and deeply bedded with straw, which permits calf nesting behavior and contributes to warmth. Snow cover on the ground may have affected where calves decided to lie down. Beef cows and heifers (Graunke et al., 2011) as well as dairy cows (Schütz et al., 2010) reduced their outdoor lying time with increased snow fall, which could explain the lower time calves spent lying outside in winter versus summer.

No differences were found between treatments with regard to where calves preferred to lay (either inside or outside the hutch) during the winter. All calves gradually increased the amount of time spent lying outside as the trial progressed, possibly due to the seasonal increase in temperature over the course of the experiment (high temperature increased from -5.5 to $7.5^{\circ} \mathrm{C}$ ), but also possibly due to improved thermoregulation by the calves as they grew (Hepola et al., 2006) or because of spatial restriction inside the hutch as the calves grew. Paired calves may have spent more time outside as the trial progressed because the individual hutches could have become uncomfortable for both calves at the same time as the calves grew. Tapki et al. (2006) found that 
calves up to 9 wk of age housed individually in larger pens $\left(4.0 \mathrm{~m}^{2}\right.$ compared with 1.5 and $\left.2.3 \mathrm{~m}^{2}\right)$ rested longer and spent less time standing than calves in smaller pens. The hutch area $\left(2.4 \mathrm{~m}^{2}\right)$ most closely compares with the medium pen $\left(2.3 \mathrm{~m}^{2}\right)$, which could be why calves preferred to lay outside toward the end of the trial. The lower critical temperature of calves decreases as they age (Hänninen et al., 2003), which could influence their behavior depending on the severity of the weather. Conducted under the same climatic conditions as the present experiment, the study by Shepley et al. (2017) showed that dairy cows with year-long outdoor exposure choose to be outside for at least $1 \mathrm{~h} / \mathrm{d}$ during the winter when given the option. However, Krohn et al. (1992) found that cows preferred to be inside when the outdoor temperature was below $0^{\circ} \mathrm{C}$. During the summer trial, it was noted that paired calves spent more time lying inside the hutch than single calves (53\% compared with 33\%). This difference could be attributable to the single calves wanting to spend more time outside to have visual contact with another calf, as preference tests have shown that calves will work for physical contact with another calf (Holm et al., 2002). Although it is unknown whether calves will work for visual access, visual contact has been shown to be beneficial to a calf's social abilities. Jensen and Larsen (2014) compared individually housed calves with calves that had either auditory or visual access to another calf and found that calves with visual access had a decreased latency to approach a novel calf compared with calves with auditory access only, suggesting that having visual access makes a calf less reluctant to interact socially with another calf. The difference between single and paired calves in the time spent inside the hutch was not seen during winter; this could be the result of the colder weather forcing single calves into the hutch for warmth.

It was noted that when paired calves were lying inside the hutch, they were more often seen lying together in the same hutch (approximately $80 \%$ of the time lying inside the hutch), which was also documented in Pempek et al. (2013). Calves may have been motivated to maintain physical contact with each other, as shown previously by Holm et al. (2002), or to keep warm in the winter (Boe and Havrevoll, 1993). Single calves spent the same amount of time inside the hutch as paired calves during wk 1 and 4 in the summer trial; during wk 1 , this coincided with $9 \mathrm{~mm}$ of precipitation, but no similar weather occurred during wk 4 . Single calves spent more time inside the hutch during wk 1 of the summer trial when it rained, so presumably the calves used the hutch for shelter from precipitation as well as shade from the sun. More research is needed to determine which conditions (e.g., climatic, physical enrichment) optimize calf utilization of resources in a mixed indoor and outdoor environment - that is, spending time both inside and outside the hutch, engaging in play behavior (Jensen et al., 2015) and other exercise opportunities. The point at which the hutch becomes too hot for the calves to stay inside in summer or at which the outdoor temperature becomes too cold for calves to stay outside in winter needs to be determined.

\section{Social Interactions and Redirected Behavior for Paired Calves}

Calves' needs for social contact with conspecifics (reviewed by Mandel et al., 2016) have been documented from the first week of age (Wood-Gush et al., 1984), and fulfilling their needs for social contacts (e.g., by paired housing) has been shown to help develop their cognitive skills (De Paula Vieira et al., 2010) and their ability to cope with environmental stressors (De Paula Veira et al., 2012). Allogrooming is considered a positive interaction between calves and an indication of social bonding (Boe and Faerevik, 2003). Bouts of allogrooming in this study showed that calves bonded socially (Sato et al., 1993). During the summer trial, allogrooming was observed to be higher in period 5 (the evening period, which was not observed during the winter trial). Faerevik et al. (2008) found that the number of allogrooming events ranged from 2.87 to 4.90 bouts/ combined $5 \mathrm{~h}$ of observation $(0.57-0.98$ bouts $/ \mathrm{h})$. The calves used in Faerevik et al. (2008) were slightly older and heavier than our calves, weighing between 89.7 and $128.5 \mathrm{~kg}$. The number of allogrooming bouts per hour reported by Faerevik et al. (2008) was lower than the number found in the present summer and winter trials, but their observations were done only in the morning (900-1130 h) and evening (1700-1930 h) rather than throughout the day as in the present study. Sato et al. (1991) conducted a study using steers and heifers over the age of $12 \mathrm{mo}$ and found 4.8 bouts/h. They also found that social licking was influenced by different aspects of the environment: it decreased on rainy days to half that seen on clear days and tended to increase when the housing environment was dirty (Sato et al., 1991). In contrast, our results did not show any differences between weeks, and the pens and hutches were maintained to provide a clean and dry environment, probably showing that the housing environment provided to calves favored positive interactions between calves.

Negative interactions, such as cross sucking and competitive displacements at the teat, can occur when a social companion is provided. Overall, the level of cross sucking was low across both the summer and winter trials and was at the lower end of the range of previous studies (e.g., 0.33-1.80 cross sucking events/d in 
Margerison et al., 2003). Cross sucking was higher during periods 1 and 5 in the summer trial, and minimal cross sucking was seen in other periods. It is unknown why cross sucking was higher in period 5 , but period 1 was a milk delivery time, which would explain why the level of occurrence was higher. Rushen and de Passillé (1995) found that milk stimulates sucking behavior and that drinking milk can lead to nonnutritive sucking. Cattle are more active in the morning and in the evening, near sunrise and sunset (Shabi et al., 2005); this could be one reason for the increase in cross sucking in period 5 during summer. The summer trial averaged 2.8 bouts/d per pen, which was 1 occurrence higher than what was found by Margerison et al. (2003) in calves that were allowed to suckle for their milk but had restricted access to the cow and therefore ingested less milk (approximately 1-2 kg/d). However, no detrimental effects, such as hair loss and sores developing in the sucked areas (Sambraus, 1980), were observed in our study, suggesting that the occurrence of cross sucking was not detrimental to the calves.

In both seasons, numbers of displacements at the teat were low. The majority of displacements were observed in periods 1 and 4 , which are the periods when fresh milk was delivered. Displacements are generally seen when calves are competing over feed, either teats or bunk space (Miller-Cushon et al., 2014). Miller-Cushon et al. (2014) found a decreased number (2.2-3.7/d compared with $10.7-11.3 /$ d) of displacements when paired calves were offered 2 teats as opposed to 1 teat per pair when fed ad libitum. In the present study 1 teat was available per calf (therefore 2 teats were available per pair); von Keyserlingk et al. (2004) recorded 18 displacements/d when a group of 3 calves was provided with 4 milk teats and 30 displacements/d when a group of 3 calves was provided with 3 milk teats, suggesting that more teats could decrease competition between calves that were fed ad libitum. In the present study, teats were placed at opposite ends of the pen to limit competition over feeding resources. Jensen et al. (2008) limit fed (6 $\mathrm{L} / \mathrm{d}$ ) calves housed in pairs and found that the number of displacements at the teat between pairs decreased when the teat was separated by a long barrier $(100 \mathrm{~cm}$; $1 / 30 \mathrm{~min}$ ) compared with a short barrier $(46 \mathrm{~cm} ; 14 / 30$ min) and no barrier (13/30 min). The displacements found in the summer and winter trials fall below the range presented by Miller-Cushon et al. (2014) for the treatment with 1 teat but are higher than the treatment with 2 teats. It could be that calves preferred to stand together to drink, and because the teats in the present study were at opposite sides of the pen, this led to the higher amount of displacements compared with the Miller-Cushon et al. (2014) treatment with 2 teats, where the teats were placed beside each other on the same side of the pen. The occurrence of displacements in our trials was similar to Jensen et al. (2008) with the long barrier; therefore, separating the teats on either side of the pen could be an alternative to physical feeding barriers to limit competition between calves.

\section{CONCLUSIONS}

Paired and single calves had similar growth rates and milk intake, which were consistent with previously reported results for high-fed calves. They showed good performance in both the summer and winter trials. All calves also had similar lying times, suggesting that calves were getting enough rest to grow similarly. All calves altered their behavior in some way to accommodate companions; paired calves were seen interacting and spending time together (i.e., lying in the same hutch), and single calves spent more time lying outside, presumably to have visual access to other calves. Physical social interactions between paired calves were seen in both the summer and winter trials. No detriments were seen from cross sucking and displacements at the teat, and the presence of allogrooming can suggest positive interactions between the paired calves in a clean environment. The doubling of all resources and the strategy to provide milk and other feeds at opposite ends of the outdoor area allowed for a noncompetitive environment, shown by the low number of displacements at the teat compared with other studies. The use of mixed indoor and outdoor housing environments tested as part of this study showed that calves make use of all resources provided to them in winter and summer conditions while maintaining good performance. Pairing calves outdoors in hutches is a good alternative to housing calves individually; however, more research is needed to assess the practicality of this method on farm and to determine how environmental conditions affect calf behavior to provide a more welfare-friendly environment to dairy calves on farm.

\section{ACKNOWLEDGMENTS}

This study was funded by the Dairy Farmers of Canada (Ottawa, Ontario, Canada), the Canadian Dairy Network (Guelph, Ontario, Canada), the Canadian Dairy Commission (Ottawa, Ontario, Canada), and Agriculture and Agri-Food Canada (Ottawa, Ontario, Canada) as part of the Dairy Science Cluster 2 initiative, supported by the AgriInnovation Program of Agriculture and Agri-Food Canada's Growing Forward 2 Policy Framework (a federal-provincial-territorial initiative). We thank all the research assistants who 
helped out with feeding and handling the calves as well as data collection and handling for both the summer and winter research trials: Jessica St John, Elise Shepley, Nancy Franco-Gendron, Maureen O'Brien, Tania Wolfe, Santiago Palacio (all 6 from University of Guelph, Alfred, Ontario, Canada), Emmanuel Laplante, Hugo Racine, Stéphanie Duhamel, Julie Beaulieu, Anne Bastin, Émilie Desjardin (all 6 from Université Sherbrooke, Sherbrooke, Québec, Canada), Jean-Michel Beaudoin, Sabrina Plante (both from Université Laval, Québec, Québec, Canada), and Tommy Perreault (École secondaire catholique régionale de Hawkesbury, Hawkesbury, Ontario, Canada). We also thank all barn staff at the former Organic Dairy Research Farm of the University of Guelph (Alfred, Ontario, Canada) for their advice and continued support in caring for the calves. We thank Dave Kelton and Georgia Mason (both from University of Guelph, Guelph, Ontario, Canada) for help with editing the manuscript as well as Roger Cue (McGill University, Ste-Anne-de-Bellevue, Quebec, Canada) for help with statistical analyses.

\section{REFERENCES}

Anderson, N. 2012. Free-access feeding of acidified milk, setting up the system using formic acid. Accessed Jun. 30, 2017. http://www. omafra.gov.on.ca/english/livestock/.

Appleby, M. 2001. Performance and feeding behaviour of calves on ad libitum milk from artificial teats. Appl. Anim. Behav. Sci. 74:191201.

Asher, L., and L. M. Collins. 2012. Assessing synchrony in groups: Are you measuring what you think you are measuring? Appl. Anim. Behav. Sci. 138:162-169.

Babu, L. K., H. N. Pandey, and A. Sahoo. 2004. Effect of individual versus group rearing on ethological and physiological response of cross-bred calves. Appl. Anim. Behav. Sci. 87:177-191.

Boe, K., and O. Havrevoll. 1993. Cold housing and computer-controlled milk feeding for dairy calves; behaviour and performance. Anim. Prod. 57:183-191.

Boe, K. E., and G. Faerevik. 2003. Grouping and social preferences in calves, heifers and cows. Appl. Anim. Behav. Sci. 80:175-190.

Bonk, S., O. Burfeind, S. V. Suthar, and W. Heuwieser. 2013. Technical note: Evaluation of data loggers for measuring lying behavior in dairy calves. J. Dairy Sci. 96:3265-3271.

Borderas, F. T., A. M. de Passillé, and J. Rushen. 2009. Temperature preferences and feed level of the newborn dairy calf. Appl. Anim. Behav. Sci. 120:56-61.

Camiloti, T. V., J. A. Fregonesi, M. A. G. von Keyserlingk, and D. M. Weary. 2012. Short communication: Effects of bedding quality on the lying behavior of dairy calves. J. Dairy Sci. 95:3380-3383.

Canadian Council on Animal Care. 2009. Guidelines on the Care and Use of Farm Animals in Research, Teaching and Testing. Canadian Council on Animal Care, Ottawa, ON, Canada.

Carter, B. H., T. H. Friend, S. M. Garey, J. A. Sawyer, M. B. Alexander, and M. A. Tomazewski. 2014. Efficacy of reflective insulation in reducing heat stress on dairy calves housed in polyethylene calf hutches. Int. J. Biometeorol. 58:51-59.

Chua, B., E. Coenen, J. van Delen, and D. M. Weary. 2002. Pair vs. individual housing on the behaviour and performance of dairy calves. J. Dairy Sci. 85:360-364.

Cobb, C. J., B. S. Obeidat, M. D. Sellers, A. R. Pepper-Yowell, and M. A. Ballou. 2014. Group housing of Holstein calves in a poor indoor environment increases respiratory disease but does not influence performance or leukocyte responses. J. Dairy Sci. 97:3099-3109.
Costa, J. H. C., R. R. Daros, M. A. G. von Keyserlingk, and D. M. Weary. 2014. Complex social housing reduces food neophobia in dairy calves. J. Dairy Sci. 97:7804-7810.

Davis, L. R., K. M. Autrey, J. Herlich, and G. E. Hawkins. 1954. Outdoor individual portable pens compared with conventional housing for raising dairy calves. J. Dairy Sci. 37:562-570.

de Passillé, A. M., B. Sweeney, and J. Rushen. 2010. Cross sucking and gradual weaning of dairy calves. Appl. Anim. Behav. Sci. 124:11-15.

de Passillé, A. M. B., J. H. M. Metz, P. Mekking, and P. R. Wiepkema. 1992. Does drinking milk stimulate sucking in young calves? Appl. Anim. Behav. Sci. 34:23-36.

De Paula Vieira, A., A. M. de Passillé, and D. M. Weary. 2012. Effects of the early social environment on behavioural responses of dairy calves to novel events. J. Dairy Sci. 95:5149-5155.

De Paula Vieira, A., M. A. G. von Keyserlingk, and D. M. Weary 2010. Effects of pair versus single housing on performance and behaviour of dairy calves before and after weaning from milk. J. Dairy Sci. 93:3079-3085

Duve, L. R., and M. B. Jensen. 2011. The level of social contact affects social behaviour in pre-weaned dairy calves. Appl. Anim. Behav. Sci. 135:34-43.

Duve, L. R., and M. B. Jensen. 2012. Social behavior of young dairy calves housed with limited or full social contact with a peer. J. Dairy Sci. 95:5936-5945.

Faerevik, G., I. L. Andersen, M. B. Jensen, and K. E. Boe. 2007. Increased group size reduces conflicts and strengthens the preference for familiar group mates after regrouping of weaned dairy calves (Bos taurus). Appl. Anim. Behav. Sci. 108:215-228.

Faerevik, G., K. Tjentland, S. Løvik, I. L. Andersen, and K. E. Bøe. 2008. Resting pattern and social behaviour of dairy calves housed in pens with different sized lying areas. Appl. Anim. Behav. Sci. 114:54-64.

Friend, T. H., J. A. Haberman, and W. R. Binion. 2014. Effect of four different reflective barriers on black-globe temperatures in calf hutches. Int. J. Biometeorol. 58:2165-2168.

Graunke, K. L., T. Schuster, and L. M. Lidfors. 2011. Influence of weather on the behavior of outdoor-wintered beef cattle in Scandinavia. Livest. Sci. 136:247-255.

Hammel, K. L., J. H. M. Metz, and P. Mekking. 1988. Sucking behaviour of dairy calves fed milk ad libitum by bucket or teat. Appl. Anim. Behav. Sci. 20:275-285.

Hänninen, L., H. Hepola, J. Rushen, A. M. de Passille, P. Pursiainen, V.-M. Tuure, L. Syrjala-Qvist, M. Pyykkonen, and H. Saloniemi. 2003. Resting behaviour, growth and diarrhea incidence rate of young dairy calves housed individually or in groups in warm or cold buildings. Acta Agric. Scand. A 53:21-28.

Hepola, H., L. Hanninen, P. Pursiainen, V. M. Tuure, L. Surjala-Qvist, M. Pyykkonen, and H. Saloniemi. 2006. Feed intake and oral behaviour of dairy calves housed individually or in groups in warm or cold buildings. Livest. Sci. 105:94-104

Hepola, H. P., L. T. Hanninen, S. M. Raussi, P. A. Pursiainen, A. M. Aarnikoivu, and H. S. Saloniemi. 2008. Effects of providing water from a bucket or a nipple on the performance and behaviour of calves fed ad libitum volumes of acidified milk replacer. J. Dairy Sci. 91:1486-1496.

Holm, L., M. B. Jensen, and L. L. Jeppeson. 2002. Calves' motivation for access to two different types of social contact measured by operant conditioning. Appl. Anim. Behav. Sci. 79:175-194.

Jensen, M. B., A. M. de Passillé, M. A. G. von Keyserlingk, and J. Rushen. 2008. A barrier can reduce competition over teats in pairhoused milk-fed calves. J. Dairy Sci. 91:1607-1613.

Jensen, M. B., L. R. Duve, and D. M. Weary. 2015. Pair housing and enhanced milk allowance increase play behaviour and improve performance in dairy calves. J. Dairy Sci. 98:2568-2575.

Jensen, M. B., and L. E. Larsen. 2014. Effects of level of social contact on dairy calf behaviour and health. J. Dairy Sci. 97:5035-5044.

Khan, M. A., D. M. Weary, and M. A. G. von Keyserlingk. 2011. Hay intake improves performance and rumen development of calves fed higher quantities of milk. J. Dairy Sci. 94:3547-3553. 
Krohn, C. C., L. Munksgaard, and B. Jonasen. 1992. Behaviour of dairy cows kept in extensive (loose housing/pasture) or intensive (tie stall) environments I. Experimental procedure, facilities, time budgets-Diurnal and seasonal conditions. Appl. Anim. Behav. Sci. 34:37-47.

Macaulay, A. S., G. L. Hahn, D. H. Clark, and D. V. Sisson. 1995. Comparison of calf housing types and tympanic temperature rhythms in Holstein calves. J. Dairy Sci. 78:856-862.

Mandel, R., H. R. Whay, E. Klement, and C. J. Nicol. 2016. Invited review: Environmental enrichment of dairy cows and calves in indoor housing. J. Dairy Sci. 99:1695-1715.

Marcé, C., R. Guatteo, N. Bareille, and C. Fourichon. 2010. Dairy calf housing systems across Europe and risk for calf infectious diseases. Animal 4:1588-1596.

Margerison, J. K., T. R. Preston, N. Berry, and C. J. C. Phillips. 2003. Cross sucking and other oral behaviours in calves and their relation to cow suckling and food provision. Appl. Anim. Behav. Sci. 80:277-286.

Meagher, R. K., R. R. Daros, J. H. C. Costa, M. A. G. von Keyserlingk, M. J. Hotzel, and D. M. Weary. 2015. Effects of degree and timing of social housing on reversal learning and response to novel objects in dairy calves. PLoS One 10:e132828. https://doi. org/10.1371/journal.pone.0132828.

Miller-Cushon, E. K., R. Bergeron, K. E. Leslie, and T. J. DeVries. 2013. Effect of milk feeding level on development of feeding behavior in dairy calves. J. Dairy Sci. 96:551-564.

Miller-Cushon, E. K., R. Bergeron, K. E. Leslie, G. J. Mason, and T. J. DeVries. 2014. Competition during the milk-feeding stage influences the development of feeding behavior of pair- housed dairy calves. J. Dairy Sci. 97:6450-6462.

Moore, D. A., J. L. Duprau, and J. R. Wenz. 2012. Short communication: Effects of dairy calf hutch elevation on heat reduction, carbon dioxide concentration, air circulation and respiratory rates. J. Dairy Sci. 95:4050-4054.

Nicol, C. J. 1995. The social transmission of information and behaviour. Appl. Anim. Behav. Sci. 44:79-98.

Ninomiya, S., and S. Sato. 2009. Effects of "five freedoms" environmental enrichment on the welfare of calves reared indoors. Anim. Sci. J. 80:347-351.

Pempek, J. A., M. L. Eastridge, N. A. Bortheras, C. C. Croney, and W. S. Bowen Yoho. 2013. Effects of alternative housing and feeding systems on the behavior and performance of dairy heifer calves. Prof. Anim. Sci. 29:278-288.

Pempek, J. A., M. L. Eastridge, S. S. Swartzwelder, K. M. Daniels, and T. T. Yohe. 2016. Housing system may affect behavior and growth performance of Jersey heifer calves. J. Dairy Sci. 99:569-578.

Redbo, I., I. Mossberg, A. Ehlermark, and M. Stahl-Hogberg. 1996. Keeping growing cattle outside during winter, behaviour, production and climatic demand. Anim. Sci. 62:35-41.
Rushen, J., and A. M. de Passillé. 1995. The motivation of non-nutritive sucking in calves, Bos taurus. Anim. Behav. 49:1503-1510.

Sambraus, H. H. 1980. Human considerations in calf rearing. Anim. Regulation Stud. 3:19-22.

SAS Institute Inc. 2011. Base SAS 9.3 Procedures Guide. SAS Institute Inc., Cary, NC.

Sato, S., S. Sako, and A. Maeda. 1991. Social licking patterns in cattle (Bos taurus): Influence of environmental and social factors. Appl. Anim. Behav. Sci. 32:3-12.

Sato, S., K. Tarumizu, and K. Hatae. 1993. The influence of social factors on allogrooming in cows. Appl. Anim. Behav. Sci. 38:235-244.

Schrama, J. W., A. Arieli, H. A. Brandsma, P. Luiting, and M. W. A. Vertegen. 1993. Thermal requirements of young calves during standing and lying. J. Anim. Sci. 71:3285-3292.

Schütz, K. E., K. V. Clark, N. R. Cox, L. R. Matthews, and C. B. Tucker. 2010. Responses to short-term exposure to simulated rain and wind by dairy cattle: Time budgets, shelter use, body temperature and feed intake. Anim. Welf. 19:375-383.

Shabi, Z., M. R. Murphy, and U. Moallem. 2005. Within-day feeding behaviour of lactating dairy cows measured using a real time control system. J. Dairy Sci. 88:1848-1854

Shepley, E., R. Bergeron, F. Bécotte, and E. Vasseur. 2017. Short communication: Dairy cow preference for outdoor access during winter under Eastern Canada climatic conditions. Can. J. Anim. Sci. 97:1-5.

Tapki, I., A. Şahin, and A. G. Önal. 2006. Effect of space allowance on behaviour of newborn milk-fed dairy calves. Appl. Anim. Behav. Sci. 99:12-20.

Tripon, I., L. T. Cziszter, M. Bura, and E. N. Sossidou. 2014. Effects of seasonal and climate variations on calves' thermal comfort and behaviour. Int. J. Biometeorol. 58:1471-1478.

USDA. 2010. Dairy 2007. Heifer Calf Health and Management Practices on U.S. Dairy Operations, 2007. USDA, Washington, DC.

Vasseur, E., F. Borderas, R. I. Cue, D. Lefebvre, D. Pellerin, J. Rushen, K. M. Wade, and A. M. de Passillé. 2010. A survey of dairy calf management practices in Canada that affect animal welfare. J. Dairy Sci. 93:1307-1315.

Veissier, I., A. M. de Passille, G. Despres, J. Rushen, I. Charpentier, A. R. Ramirez de la Fe, and P. Pradel. 2002. Does nutritive and non-nutritive sucking reduce other oral behaviours and stimulate rest in calves? J. Anim. Sci. 80:2574-2587.

von Keyserlingk, M. A. G., L. Brusius, and D. M. Weary. 2004. Competition for teats and feeding behaviour by group-housed dairy calves. J. Dairy Sci. 87:4190-4194.

Wood-Gush, D. G. M., K. A. Hunt, K. Carson, and S. G. C. Dennison. 1984. The early behaviour of suckler calves in the field. Biol. Behav. 9:295-306. 